\title{
MENINGKATKAN KEMAMPUAN LITERASI MATEMATIS DENGAN PENDEKATAN METACOGNITIVE GUIDANCE BERBANTUAN GEOGEBRA
}

\author{
(IMPROVING MATHEMATICAL LITERACY SKILLS USING \\ METACOGNITIVE GUIDANCE APPROACH ASSISTED BY GEOGEBRA)
}

\author{
Khotimah \\ STKIP Pelita Pratama, khotimah_math08@yahoo.com
}

\begin{abstract}
Abstrak
Penelitian ini dilatarbelakangi oleh hasil studi pendahuluan mengenai kemampuan literasi matematis di salah satu SMP Negeri Kota Serang. Tujuan utama penelitian ini untuk menyelidiki peningkatan kemampuan literasi matematis siswa, sebagai akibat dari pembelajaran dengan pendekatan Metacognitive Guidance berbantuan GeoGebra (MG+GeoGebra) dan pembelajaran biasa (PB) yang ditinjau dari kategori PAM (tinggi, sedang, dan rendah). Penelitian ini termasuk ke dalam non equivalent pretest - postest - control group design. Hasil analisis data menyimpulkan bahwa: 1.a) ditinjau secara keseluruhan, peningkatan kemampuan literasi matematis siswa yang mendapatkan pembelajaran $\mathrm{MG}+\mathrm{GeoGebra}$ lebih baik daripada siswa yang mendapatkan pembelajaran PB; 1.b) peningkatan kemampuan literasi matematis siswa kategori PAM tinggi dan sedang pada kelompok eksperimen lebih baik dibandingkan dengan siswa kategori PAM tinggi dan sedang pada kelompok kontrol; 2) tidak terdapat interaksi antara faktor pembelajaran yang diberikan dan kategori PAM (tinggi, sedang, dan rendah) terhadap kemampuan literasi matematis.
\end{abstract}

Kata kunci: Metacognitive Guidance, GeoGebra, Literasi Matematis

\begin{abstract}
The purpose of this research was to investigate the effects of Metacognitive Guidance Approach assisted by GeoGebra on mathematical literacy. In particular, the study compares two learning environment: a) conventional learning, and b) metacognitive guidance learning using GeoGebra. This study was carried out on student"s ability level (low, medium and high ability group), and their competence on mathematical literacy. This research was non equivalent pretest - postest - control group design. The results of data analysis showed that: 1.a) the students who were exposed to MG+GeoGebra outperform students that were not exposed to MG+GeoGebra on mathematical literacy; 1.b) the students in high and medium ability group who were exposed to MG+GeoGebra outperform students that were not exposed to MG+GeoGebra on mathematical literacy; 2) there was no interaction between learning method and student"s ability level on mathematical literacy.
\end{abstract}

Keywords: Metacognitive Guidance, GeoGebra, Mathematical Literacy 


\section{PENDAHULUAN}

Matematika merupakan salah mata pelajaran yang memiliki kontribusi besar dalam kehidupan manusia. Kontribusi matematika itu dapat dilihat dari banyaknya aspek kehidupan manusia yang menggunakan konsep-konsep dasar matematika, mulai dari aljabar, aritmetika hingga geometri (Sarwiko, 2010: 1). Hampir semua bidang studi memerlukan matematika. Oleh sebab itu, semua orang harus mempelajari matematika agar dapat digunakan sebagai sarana untuk memecahkan masalah kehidupan sehari-hari. Selain itu, matematika merupakan ilmu universal yang mendasari perkembangan teknologi modern, mempunyai peran penting dalam berbagai disiplin dan memajukan daya pikir manusia (BSNP, 2006: 345).

Sejalan dengan hal tersebut, menurut Rubyanto, (dalam Sutama, 2008: 114) matematika sekolah diberikan kepada siswa untuk membekali siswa berpikir logis, analitis, sistematis, kritis, dan kreatif serta mampu bekerja sama. Kompetensi tersebut diperlukan agar siswa memiliki kemampuan memperoleh, mengelola, dan memanfaatkan informasi untuk bertahan hidup pada keadaan yang selalu berubah, tidak pasti dan kompetitif.

NCTM atau National Council of Teachers Mathematics (Maryanti, 2012: 5) menjabarkan tujuan diberikannya mata pelajaran matematika ke dalam lima kompetensi matematika yang harus dimiliki siswa, yaitu: pemecahan masalah matematis (mathematical problem solving), komunikasi matematis (mathematical communication), penalaran matematis (mathematical reasoning), koneksi matematis (mathematical connection), dan representasi matematis (mathematical representation). Kemampuan yang mencakup kelima kompetensi di atas adalah kemampuan literasi matematis. Kemampuan literasi matematis merupakan kemampuan individu yang mencakup kemampuan merumuskan, menerapkan, dan menafsirkan matematika dalam berbagai konteks yang melibatkan penalaran matematis dan penggunaan konsep, prosedur, fakta, dan alat matematika untuk mendeskripsikan, menjelaskan, dan memprediksi fenomena, serta mengaitkannya dengan kehidupan sehari-hari.

Kemampuan literasi matematis berkaitan dengan bagaimana seorang siswa dapat mengaplikasikan suatu pengetahuan dalam masalah dunia nyata (real world) atau kehidupan sehari-hari, sehingga pengetahuan tersebut dapat dirasa lebih kebermanfaatan secara langsung oleh siswa. Dengan demikian, kemampuan literasi matematis seorang siswa lebih dipengaruhi oleh pengalaman siswa itu sendiri. Oleh sebab itu, pembelajaran matematika sebaiknya merupakan usaha dalam mengarahkan siswa mengkontruksi pengetahuan melalui proses. Karena mengetahui bukanlah sebuah produk/hasil tetapi suatu proses yang dimulai dari pengalaman, sehingga siswa sebaiknya diberi kesempatan seluas-luasnya untuk mengkontruksi pengetahuan yang harus dimiliki. Dengan mengetahui sebaran dan rumusan dasar mengenai kemampuan literasi matematis siswa, guru dapat mempertimbangkan metode pembelajaran yang dikembangkan dan instrumen penilaian yang digunakan serta dapat mengembangkan aspek kemampuan literasi matematis siswa yang masih rendah (Oktaviyanthi, Agus \& Supriani, 2015).

Berdasarkan hasil studi pendahuluan dan observasi yang dilakukan oleh peneliti di salah satu SMP Negeri Serang, diperoleh temuan bahwa kemampuan literasi matematis siswa masih kurang menggembirakan dan tampaknya perlu ditingkatkan. Hal ini kemungkinan disebabkan oleh beberapa faktor, diantaranya adalah, pada kondisi tertentu, kesulitan yang dialami oleh siswa ketika 
menyelesaikan soal kemampuan literasi matematis bukan disebabkan oleh rendahnya kemampuan matematisnya, namun karena kebiasaan membaca yang masih perlu diasah. Dalam beberapa kasus, siswa tidak dapat memperoleh informasi esensial dan strategis dalam membaca soal-soal literasi matematis yang berkaitan dengan kehidupan sehari-hari. Selain itu, aspek psikologis yang mungkin turut memberikan pengaruh adalah kurangnya tingkat keyakinan terhadap kemampuan mereka sendiri dalam menyelesaikan soal matematika. Ketika menghadapi soal yang, „terlihat ${ }^{\text {ee }}$ lebih rumit, siswa cenderung mudah menyerah dan menganggap kegagalan berasal dari kurangnya kemampuan matematisnya. Hal lain yang menjadi salah satu penyebab suatu konsep tidak tersampaikan pada peserta didik dikarenakan ketidaktepatan metode yang digunakan dalam proses penyampaian (Oktaviyanthi \& Herman, 2016).

Berdasarkan permasalahan di atas, maka dibutuhkan sebuah pendekatan dalam pembelajaran matematika yang mampu mengaktifkan siswa untuk mengonstruksi pengetahuannya, sehingga siswa memiliki kesadaran tentang apa yang sudah diketahui dan apa yang belum diketahuinya serta bagaimana mereka memikirkan agar dapat menyelesaikan suatu permasalahan. Sejalan dengan pernyataan Steen (1997), bahwa pembelajaran matematika merupakan proses membangun kesadaran siswa untuk mengetahui bagaimana dan kapan dia menggunakan pengetahuannya. Salah satu alternatif pendekatan pembelajaran yang cukup relevan untuk digunakan adalah pendekatan metacoginitive guidance. Pendekatan ini menawarkan beberapa langkah-langkah yang sejalan dengan indikator kemampuan literasi matematis, diantaranya adalah siswa belajar bagaimana mengontrol aktifitas berpikirnya, berpikir tentang proses berpikir mereka khususnya dalam memahami masalah, mempertimbangkan strategi dalam menyelesaikan masalah, serta melakukan refleksi pada proses dan solusi yang dilakukan. Untuk itu peneliti tertarik untuk melakukan penelitian yang berjudul "Meningkatkan Kemampuan Literasi Matematis dengan Pendekatan Metacognitive Guidance Berbantuan GeoGebra".

Selain faktor pembelajaran, ada faktor lain yang diduga dapat mendorong peningkatan kemampuan literasi matematis, yaitu kategori PAM (tinggi, sedang, dan rendah). Oleh sebab itu, dalam penelitian ini, peningkatan kemampuan literasi matematis ditinjau secara keseluruhan maupun berdasarkan masing-masing kategori PAM (tinggi, sedang, dan rendah). Dengan demikian, akan terlihat pula apakah terdapat interaksi antara faktor pembelajaran (pembelajaran dengan pendekatan Metacognitive Guidance berbantuan GeoGebra dengan pembelajaran biasa) dan kategori PAM (tinggi, sedang, dan rendah) terhadap peningkatan kemampuan literasi matematis.

\section{KAJIAN TEORI}

\section{A. KEMAMPUAN LITERASI MATEMATIS}

Secara formal, definisi literasi matematika dalam kerangka PISA matematika 2012 menurut Stacey (2012) dan OECD (2013) adalah sebagai berikut:

"Mathematical literacy is an individual's capacity to formulate, employ, and interpret mathematics in a variety of contexts. It includes reasoning mathematically and using mathematical concepts, procedures, facts, and tools 
to describe, explain, and predict phenomena. It assists individuals to recognise the role that mathematics plays in the world and to make the wellfounded judgments and decisions needed by constructive, engaged and reflective citizens."

Sedangkan menurut Kusumah (dalam Maryanti, 2012: 16), „literasi matematis adalah kemampuan menyusun serangkaian pertanyaan (problem posing), merumuskan, memecahkan dan menafsirkan permasalahan yang didasarkan pada konteks yang ada ${ }^{e e}$. Senada dengan definisi literasi matematis menurut Isnaini (dalam Maryanti, 2012: 16), yaitu kemampuan peserta didik untuk dapat mengerti fakta, konsep, prinsip, operasi, dan pemecahan masalah matematika. Berdasarkan definisi tersebut, kemampuan literasi matematis merupakan kemampuan individu yang mencakup kemampuan merumuskan, menerapkan, dan menafsirkan matematika dalam berbagai konteks yang melibatkan penalaran matematis dan penggunaan konsep, prosedur, fakta, dan alat matematika untuk mendeskripsikan, menjelaskan, dan memprediksi fenomena, serta mengaitkannya dengan kehidupan sehari-hari.

Pengukuran kemampuan literasi matematis dalam penelitian ini difokuskan pada indikator-indikator yang diturunkan dari level kemampuan literasi matematis tersebut. Berikut ini adalah tabel indikator kemampuan literasi matematis yang digunakan dalam penelitian ini:

Tabel 1. Indikator Kemampuan Literasi Matematis

Aspek Literasi

Matematika

\begin{tabular}{lc}
\hline $\begin{array}{l}\text { Merumuskan masalah } \\
\text { secara matematis }\end{array}$ & $\begin{array}{c}\text { Mengidentifikasi masalah ke dalam bentuk } \\
\text { matematika }\end{array}$ \\
Menggunakan fakta, & - Melakukan penalaran berdasarkan fakta-fakta \\
konsep, prosedur, dan & yang diberikan \\
penalaran matematis & - Menentukan prosedur yang akan digunakan \\
& berdasarkan asumsi-asumsi yang telah \\
& diberikan di dalam soal \\
& - Memilih dan menerapkan strategi pemecahan \\
Menafsirkan, & masalah yang sederhana berdasarkan fakta \\
menerapkan, dan & atau sumber yang berbeda \\
mengevaluasi hasil dari & - Mengkomunikasikan penjelasan dengan \\
suatu proses matematika & memberikan argumen berdasarkan interpretasi \\
& terhadap permasalahan yang diajukan \\
\hline
\end{tabular}

\section{B. PENDEKATAN METACOGNITIVE GUIDANCE}

Metakognisi (metacognitive) merupakan suatu istilah yang diperkenalkan oleh Flavell pada tahun 1979. Definisi metakognisi menurut Flavell (1979) adalah kesadaran seseorang tentang bagaimana ia belajar, kemampuan untuk menilai kesukaran sesuatu masalah, kemampuan untuk mengamati tingkat pemahaman dirinya, kemampuan menggunakan berbagai informasi untuk mencapai tujuan, dan kemampuan menilai kemajuan belajar sendiri. Sementara Dirkes (dalam 
Osborne \& Monk, 2000) mendefinisikan metakognisi sebagai kemampuan untuk mengidentifikasi apa yang sudah diketahui (what you know) dan apa yang belum diketahui (what you don't know), mengaitkan informasi atau pengetahuan baru dengan pengetahuan yang sudah diperoleh sebelumnya, merencanakan strategi penyelesaian, serta meminor dan mengevaluasi proses berpikir yang dilakukan. Sejalan dengan definisi tersebut, Tim MKPBM (2001) memandang metakognitif sebagai suatu bentuk kemampuan untuk melihat pada diri sendiri sehingga apa yang dia lakukan dapat terkontrol secara optimal. Para peserta didik dengan pengetahuan metakognitifnya sadar akan kelebihan dan keterbatasannya dalam belajar. Artinya saat siswa mengetahui kesalahannya, mereka sadar untuk mengakui bahwa mereka salah, dan berusaha untuk memperbaikinya.

Berdasarkan beberapa definisi tersebut, dapat disimpulkan bahwa metakognisi adalah kesadaran berpikir seorang individu dalam memantau dan mengendalikan pikiran. Dengan kata lain, metakognisi memberikan penekanan pada kesadaran berpikir seseorang tentang proses berpikirnya sendiri. Dalam konteks pembelajaran, metakognisi merupakan kesadaran berpikir siswa dalam memonitor (mengawasi), merencanakan serta mengevaluasi sebuah proses pembelajaran. Hal ini sejalan dengan pernyataan McGuinness (1999):

"It is important to give learners the time and opportunity to talk about thinking processes, to make their own thought processes more explicit, to reflect on their strategies and thus gain more self-control. Acquiring and using metacognitive skills has emerged as a powerful idea for promoting a thinking skills curriculum."

Berdasarkan pernyataan tersebut, dapat disimpulkan bahwa pendekatan metacognitive guidance adalah pendekatan pembelajaran yang menanamkan kesadaran bagaimana merancang, memonitor, serta mengontrol tentang apa yang mereka ketahui; apa yang diperlukan untuk mengerjakan dan bagaimana melakukannya. Pembelajaran dengan pendekatan metacognitive guidance menitikberatkan pada aktivitas belajar siswa; membantu dan membimbing siswa jika ada kesulitan; serta membantu siswa untuk mengembangkan konsep diri apa yang dilakukan saat belajar matematika.

Menurut Pratiwi dan Syah (2011: 345) tahap pembelajaran dengan pendekatan metacognitive guidance meliputi tahapan sebagai berikut: (1) tahap proses sadar yaitu melalui proses menentukan tujuan belajar, menentukan sumber belajar, menentukan penilaian yang baik dalam pembelajaran, menentukan tingkat motivasi belajar dan tingkat kesulitan siswa; (2) tahap merencanakan belajar untuk menentukan skala prioritas belajar, mengorganisasi pembelajaran, dan menggunakan berbagai strategi belajar seperti outlining, mind mapping dan strategi belajar lain; (3) tahap monitoring dan refleksi belajar melalui pertanyaan seperti, bertanya apakah materi ini bermanfaat buat saya?

\section{GEOGEBRA}

Dalam era globalisasi ini, pemanfaatan teknologi dalam proses pembelajaran merupakan suatu hal yang mutlak diperlukan. Bahan ajar matematika yang memanfaatkan komputer sebagai media pembelajaran, tentunya dapat memberikan poin lebih dibandingkan dengan pembelajaran biasa yang hanya mengandandalkan spidol, kapur, dan papan tulis dalam proses belajar 
mengajar. Hal ini dikarenakan komputer sebagai media pembelajaran interaktif memiliki nilai lebih dalam menjelaskan konsep dan dapat mempermudah siswa memahami materi (Supriani \& Oktaviyanthi, 2014; Oktaviyanthi \& Herman, 2016). Kusumah mengemukakan bahwa program-program komputer sangat ideal untuk dimanfaatkan dalam pembelajaran konsep-konsep matematika yang menuntut ketelitian tinggi, konsep atau prinsip yang repetitif, penyelesaian grafik secara tepat, cepat, dan akurat (Mahmudi, 2011:2).

Sejalan dengan hal tersebut, Kusumah (Mahmudi, 2011: 2) juga mengemukakan bahwa inovasi pembelajaran dengan bantuan komputer sangat baik untuk diintegrasikan dalam pembelajaran konsep-konsep matematika, terutama yang menyangkut transformasi geometri, kalkulus, statistika, dan grafik fungsi. Dengan mengintegrasikan teknologi ke dalam proses pengajaran dan pembelajaran matematika, diharapkan dapat meningkatkan kemampuan peserta didik dalam memahami ide-ide kompleks dan mampu mengonstruksi pemecahan masalah matematika (Oktaviyanthi \& Supriani, 2015). Disamping itu, pembelajaran matematika berbantuan teknologi dapat membantu siswa terlibat lebih aktif dan luas dalam menghubungkan dunia sekolah dengan dunia nyata (Oktaviyanthi, Safaah \& Agus, 2017). Salah satu program komputer yang dapat dimanfaatkan sebagai media pembelajaran matematika adalah program GeoGebra yang dikembangkan oleh Markus Hohenwarter pada tahun 2001.

GeoGebra merupakan software matematika yang sangat bermanfaat bagi guru maupun siswa. Tidak seperti software komersial yang biasanya hanya bisa dimanfaatkan di sekolah, GeoGebra dapat diinstal pada komputer pribadi dan dimanfaatkan kapan dan di manapun oleh siswa maupun guru secara gratis. Selain itu, bagi guru, GeoGebra menawarkan kesempatan yang efektif untuk mengkreasi lingkungan belajar online interaktif yang memungkinkan siswa mengeksplorasi berbagai konsep-konsep matematis (Mahmudi, 2011: 2). Diantara keunggulan software GeoGebra adalah dapat digunakan sebagai media demonstrasi dan visualisasi. Dalam hal ini, guru dapat memanfaatkan GeoGebra untuk mendemonstrasikan dan memvisualisasikan konsep-konsep matematika tertentu.

Selain itu, GeoGebra juga dapat digunakan sebagai alat bantu konstruksi. Dalam hal ini, GeoGebra digunakan untuk memvisualisasikan gambar maupun ilustrasi, sehingga siswa dapat mengkonstruksi sendiri pola pikirnya untuk memahami konsep secara mandiri. Keunggulan GeoGebra dalam pembelajaran matematika diantaranya adalah sebagaai berikut: a) dapat menghasilkan lukisanlukisan geometri dengan cepat dan teliti dibandingkan dengan menggunakan pensil, penggaris, atau jangka, b) adanya fasilitas animasi dan gerakan-gerakan manipulasi (dragging) pada GeoGebra dapat memberikan pengalaman visual yang lebih jelas kepada siswa dalam memahami konsep geometri, c) dapat dimanfaatkan sebagai balikan/evaluasi untuk memastikan bahwa lukisan yang telah dibuat benar, d) mempermudah guru/siswa untuk menyelidiki atau menunjukkan sifat - sifat yang berlaku pada suatu objek geometri.

\section{METODE PENELITIAN}

Penelitian ini merupakan bentuk penelitian kuasi eksperimen dan termasuk ke dalam non equivalent pretest - postest - control group design. Populasi dalam penelitian ini adalah seluruh siswa kelas VIII SMP Negeri 2. Pengambilan sampel pada penelitian ini dilakukan dengan menggunakan teknik purposive sampling 
(sampel acak bertujuan). Sampel dalam penelitian adalah siswa kelas VIII SMP Negeri 2 Serang sebanyak dua kelas dengan kategori kemampuan yang sama sebagai kelompok eksperimen dan kelompok kontrol.

Instrumen dalam penelitian ini meliputi: bahan ajar berbantuan GeoGebra, instrumen tes kemampuan literasi matematis dan pedoman observasi yang memuat item-item aktivitas guru dan siswa dalam pembelajaran. Data yang dianalisis adalah data skor pretes siswa kelas eksperimen dan kelas kontrol untuk melihat gambaran tentang kemampuan awal kedua kelas, sedangkan analisis skor $\mathrm{N}$-Gain digunakan mengukur peningkatan kemampuan literasi matematis siswa pada kelompok eksperimen dan kelompok kontrol setelah mendapatkan perlakuan pembelajaran dengan pendekatan Metacognitive Guidance berbantuan GeoGebra dan pembelajaran biasa. Uji statistik yang digunakan untuk menguji hipotesis adalah uji-t (Independent Sample t-Test), uji Mann-Whitney, dan uji ANOVA (analysis of variance) dua jalur dengan interaksi.

Pada penelitian ini, peneliti langsung berperan sebagai guru yang melaksanakan pembelajaran pada kelas eksperimen dengan menerapkan pembelajaran dengan pendekatan Metacognitive Guidance berbantuan GeoGebra. Aktivitas siswa dan guru selama proses pembelajaran dianalisis sebagai bahan evaluasi dalam mengimplementasikan pembelajaran dengan pendekatan Metacognitive Guidance berbantuan GeoGebra. Evaluasi proses pembelajaran ini diakukan melalui pedoman observasi aktivitas guru dan siswa sebagaimana terlampir. Evaluator atau observer dalam penelitian ini adalah guru matematika di sekolah tempat penelitian dilakukan. Observasi ini dilakukan selama proses pembelajaran berlangsung.

Observasi yang dilakukan terhadap guru bertujuan untuk mengetahui apakah guru sudah menerapkan pendekatan Metacognitive Guidance berbantuan GeoGebra sudah sesuai dengan skenario pembalajaran yang disusun. Sedangkan observasi tentang aktivitas siswa dilakukan untuk melihat sejuah mana pembelajaran dengan pendekatan Metacognitive Guidance berbantuan GeoGebra dilaksanakan oleh siswa pada saat proses pembelajaran berlangsung.

\section{HASIL DAN PEMBAHASAN}

\section{A. HASIL PENELITIAN}

Penelitian ini bertujuan untuk untuk menyelidiki, membandingkan dan mendeskripsikan secara komprehensif tentang peningkatan kemampuan literasi matematis siswa yang mendapatkan pembelajaran dengan pendekatan metacognitive guidance berbantuan GeoGebra dan siswa yang mendapatkan pembelajaran biasa ditinjau dari: a) keseluruhan, dan b) masing-masing kategori PAM (tinggi, sedang, dan rendah) serta interaksi antara faktor pembelajaran yang diberikan dan kategori PAM (tinggi, sedang, rendah) terhadap kemampuan literasi matematis siswa. Selain itu, penelitian ini juga bertujuan menyelidiki, membandingkan dan mendeskripsikan secara komprehensif tentang self-efficacy siswa yang mendapatkan pembelajaran dengan pendekatan metacognitive guidance berbantuan GeoGebra dan siswa yang mendapatkan pembelajaran biasa ditinjau dari: a) keseluruhan, b) masing-masing kategori PAM (tinggi, sedang, dan rendah).

Data yang dianalisis berasal dari 82 orang siswa yang terdiri dari 41 siswa pada kelompok eksperimen dan 41 siswa pada kelompok kontrol. Data yang 
dianalisis adalah data skor pretes siswa kelas eksperimen dan kelas kontrol untuk melihat gambaran tentang kemampuan awal kedua kelas, sedangkan analisis hasil postes siswa kelas eksperimen dan kelas kontrol digunakan untuk melihat perbedaan kemampuan masing-masing kelas sekaligus mengukur peningkatan kemampuan literasi matematis ( $N$-Gain), serta analisis hasil self-efficacy siswa kelompok eksperimen dan kelompok kontrol untuk melihat gambaran self-efficacy siswa setelah mendapatkan perlakuan pembelajaran dengan pendekatan metacognitive guidance berbantuan GeoGebra dan pembelajaran biasa. Pengolahan data dilakukan dengan bantuan program software SPSS 17 for windows dan Microsoft Excel.

Berikut ini adalah statistik deskriptif skor pretes, postes, dan $N$-Gain kemampuan literasi matematis secara keseluruhan maupun berdasarkan masingmasing kategori PAM (tinggi, sedang, dan rendah), baik pada kelas eksperimen maupun pada kelas kontrol dapat dilihat pada tabel berikut:

Tabel 2. Statistik Deskriptif Skor Pretes, Postes, dan N-Gain Literasi Matematis secara Keseluruhan

\begin{tabular}{|c|c|c|c|c|c|c|c|}
\hline \multirow{2}{*}{$\begin{array}{c}\text { Kategori } \\
\text { PAM }\end{array}$} & & \multicolumn{3}{|c|}{ Eksperimen } & \multicolumn{3}{|c|}{ Kontrol } \\
\hline & & Pretes & Postes & N-Gain & Pretes & Postes & N-Gain \\
\hline \multirow[t]{3}{*}{ Tinggi } & $\mathbf{n}$ & & 8 & & & 8 & \\
\hline & $\bar{x}$ & 11,5 & 32 & $\mathbf{0 , 5 9}$ & 14 & 29,38 & 0,44 \\
\hline & $\mathbf{S}$ & 4,00 & 3,16 & 0,09 & 3,55 & 3,38 & 0,14 \\
\hline \multirow[t]{3}{*}{ Sedang } & $\mathbf{n}$ & & 25 & & & 25 & \\
\hline & $\bar{x}$ & 8,92 & 27,12 & $\mathbf{0 , 5 2}$ & 9,52 & 22,96 & 0,38 \\
\hline & $\mathbf{S}$ & 4,90 & 3,88 & 0,19 & 4,12 & 4,44 & 0,16 \\
\hline \multirow[t]{3}{*}{ Rendah } & $\mathbf{n}$ & & 5 & & & 5 & \\
\hline & $\bar{x}$ & 8 & 24,25 & 0,46 & 4,5 & 20,38 & 0,45 \\
\hline & $\mathbf{S}$ & 3,46 & 4,89 & 0,21 & 1,69 & 2,92 & $\mathbf{0 , 1 0}$ \\
\hline \multirow[t]{3}{*}{ Keseluruhan } & $\mathbf{n}$ & & 41 & & & 41 & \\
\hline & $\bar{x}$ & 9,25 & 27,51 & 0,521 & 9,41 & 23,71 & 0,408 \\
\hline & $\mathbf{S}$ & 4,55 & 4,61 & 0,183 & 4,68 & 4,93 & 0,146 \\
\hline
\end{tabular}

Berdasarkan tabel statistik deskriptif skor pretes, postes, dan $\mathrm{N}$-Gain kemampuan literasi matematis berdasarkan masing-masing kategori PAM di atas, terlihat bahwa rerata $N$-Gain pada kategori PAM tinggi pada kelompok eksperimen lebih tinggi dibandingkan kelompok kontrol. Begitu juga dengan rerata $\mathrm{N}$-Gain pada kategori PAM sedang. Rerata $N$-Gain kategori PAM tinggi pada kelompok eksperimen dan kelompok kontrol masing-masing 0,59 dan 0,44. Rerata $N$-Gain kategori PAM sedang pada kelompok eksperimen dan kelompok kontrol masing-masing 0,52 dan 0,38. Sedangkan rerata $N$-Gain kategori PAM rendah pada kelompok eksperimen dan kelompok kontrol tidak memperlihatkan perbedaan yang signifikan, masing-masing 0,45 dan 0,46 .

Meskipun demikian, untuk melihat signifikansi perbedaan peningkatan kemampuan literasi matematis antara kelompok eksperiman dan kelompok kontrol, baik ditinjau secara keseluruhan maupun berdasarkan masing-masing kategori PAM, perlu dilakukan analisis uji perbedaan rerata. Berikut ini adalah 
tabel hasil pengujian perbedaan rerata $\mathrm{N}$-Gain kemampuan literasi matematis secara keseluruhan.

Tabel 3. Hasil Uji Perbedaan Rerata Data Skor N-Gain Kemampuan Literasi Matematis secara Keseluruhan

\begin{tabular}{ccc}
\hline $\begin{array}{c}\text { t-test for Equality of Means } \\
\text { Sig. (2-tailed) }\end{array}$ & Sig. (1-tailed) & Kesimpulan \\
\hline 0,002 & 0,001 & $\mathrm{H}_{0}$ ditolak \\
\hline
\end{tabular}

Berdasarkan tabel di atas, dapat disimpulkan bahwa peningkatan kemampuan literasi matematis siswa kategori PAM sedang pada kelompok eksperimen yang memperoleh pembelajaran dengan pendekatan Metacognitive Guidance berbantuan GeoGebra lebih baik secara signifikan dibandingkan dengan siswa kategori PAM sedang pada kelompok kontrol yang memperoleh pembelajaran biasa. Berikut ini adalah sasil analisis uji perbedaan dua rerata skor pretes kemampuan literasi matematis masing-masing kategori PAM (Tinggi, Sedang, dan Rendah).

Tabel 4. Hasil Uji Perbedaan Peringkat Data skor N-Gain Kategori PAM (Tinggi, Sedang, dan Rendah)

\begin{tabular}{cccc}
\hline PAM & Uji Statistik & Sig. & Kesimpulan \\
\hline Tinggi & Mann-Whitney & 0,017 & $\mathrm{H}_{0}$ ditolak \\
Sedang & Uji-t & 0,014 & $\mathrm{H}_{0}$ ditolak \\
Rendah & Uji-t' & 0,451 & $\mathrm{H}_{0}$ diterima \\
\hline
\end{tabular}

Kesimpulan yang diperoleh berdasarkan pengujian statistik di atas yaitu: peningkatan kemampuan literasi matematis siswa kategori PAM tinggi dan sedang pada kelompok eksperimen yang mendapatkan pembelajaran dengan pendekatan Metacognitive Guidance berbantuan GeoGebra lebih baik dibandingkan dengan siswa kategori PAM tinggi dan sedang pada kelompok kontrol yang mendapatkan pembelajaran biasa. Sedangkan peningkatan kemampuan literasi matematis siswa kategori PAM rendah pada kelompok eksperimen tidak berbeda secara signifikan dengan siswa kategori PAM rendah pada kelompok kontrol.

Selanjutnya, uji statistik ANOVA dua jalur dengan interaksi digunakan untuk menguji hipotesis penelitian kedua, yaitu "terdapat interaksi antara faktor pembelajaran yang diberikan dan kategori PAM (tinggi, sedang, rendah) terhadap kemampuan literasi matematis". Uji statistik ini digunakan untuk mengetahui apakah ada interaksi antara dua faktor, yaitu faktor pembelajaran yang diberikan pada kedua kelompok dan kategori PAM (tinggi, sedang, dan rendah) terhadap peningkatan kemampuan literasi matematis.

Tabel 5. Hasil Uji ANOVA Dua Jalur dengan Interaksi Data skor N-Gain

\begin{tabular}{cc}
\hline $\begin{array}{c}\text { Test of Between-Subjects } \\
\text { Fakterts }\end{array}$ & Sig. \\
\hline Pembelajaran & 0,023 \\
PAM & 0,446 \\
Pembelajaran*PAM & 0,378 \\
\hline
\end{tabular}


Berdasarkan hasil uji ANOVA dua jalur dengan interaksi pada Tabel 4, dapat ditarik kesimpulan bahwa tidak terdapat interaksi antara faktor pembelajaran dan kategori PAM terhadap peningkatan kemampuan literasi matematis. Artinya, karakteristik perbedaan antara siswa kategori PAM tinggi, sedang, dan rendah untuk setiap faktor pembelajaran yang diberikan adalah sama. Dengan kata lain, faktor kategori PAM tidak berpengaruh signifikan terhadap peningkatan kemampuan literasi matematis.

\section{B. PEMBAHASAN}

Secara umum, pelaksanaan pembelajaran dengan pendekatan Metacognitive Guidance berbantuan GeoGebra ini berjalan dengan baik. Secara garis besar mengikuti tahapan-tahapan pembelajaran yang digambarkan dalam Rencana Pelaksanaan Pembelajaran (RPP), dengan alokasi waktu pembelajaran untuk satu kali pertemuan selama 2 jam pelajaran (70 menit) dan 3 jam pelajaran (105 menit).

Sebelum penelitian dilaksanakan, peneliti melakukan observasi mengenai kegiatan pembelajaran yang diterapkan oleh guru bidang studi di kelas yang akan dijadikan sebagai kelompok eksperimen dan kelompok kontrol. Hal tersebut dilakukan agar peneliti mendapatkan informasi atau gambaran umum mengenai keadaan kelas, kemampuan siswa, dan bagaimana kegiatan pembelajaran berlangsung. Selain itu, peneliti juga melakukan diskusi dengan guru bidang studi mengenai kegiatan pembelajaran yang akan dilaksanakan dan mengkonfirmasi ketersediaan sarana dan prasarana yang diperlukan selama proses penelitian, misalnya infocus dan laptop, khususnya untuk kelompok eksperimen. Pada saat kegiatan observasi berlangsung, peneliti juga melakukan penginstalan software GeoGebra pada beberapa laptop siswa kelompok eksperimen dan membagikan soft-file berupa bahan ajar berupa applet GeoGebra yang akan digunakan selama pembelajaran berlangsung.

Kegiatan pembelajaran diawali dengan pemberian apersepsi pada siswa, guru memberikan motivasi kepada siswa dengan menjelaskan manfaat materi yang akan dipelajari siswa. Selanjutnya, Guru menginformasikan tentang pendekatan pembelajaran yang akan digunakan dalam pembelajaran serta pentingnya berdiskusi, mengemukakan pendapat, dan bertanya pada diri sendiri mengenai apa yang sudah diketahui, apa yang belum diketahui serta memikirkan strategi apa yang harus dilakukan untuk menyelesaikan suatu permasalahan matematika. Siswa diarahkan untuk duduk secara berkelompok kemudian guru memulai pembelajaran dengan menyajikan permasalahan kontekstual yang disajikan melalui Lembar Kerja Siswa (LKS) yang terlebih dahulu telah dibagikan kepada siswa, sebelum pembelajaran berlangsung. Selanjutnya, siswa diminta membaca LKS yang telah diberikan kemudian mendiskusikannya bersama dengan kelompoknya untuk menyelesaikan permasalahan yang disajikan dalam LKS, guru berkeliling memperhatikan aktivitas siswa, sambil sesekali mengajukan pertanyaan bimbingan jika diperlukan.

Temuan dan hasil penelitian memperlihatkan bahwa siswa yang memperoleh pembelajaran dengan pendekatan Metacognitive Guidance berbantuan GeoGebra memperoleh hasil yang lebih baik dibandingkan dengan siswa yang belajar dengan pembelajaran biasa. Hal ini dimungkinkan karena 
pembelajaran dengan pendekatan Metacognitive Guidance berbantuan GeoGebra ini merupakan suatu pendekatan pembelajaran yang lebih menekankan pada keaktifan siswa untuk mampu merekonstruksi pengetahuan mereka sendiri, melalui permasalahan nyata yang diberikan dan tentunya permasalahan tersebut erat kaitannya dengan kehidupan para siswa itu sendiri.

Selain itu, pendekatan ini juga menawarkan beberapa langkah-langkah yang sejalan dengan indikator kemampuan literasi matematis, diantaranya adalah siswa belajar bagaimana mengontrol aktifitas berpikirnya, berpikir tentang proses berpikir mereka khususnya dalam memahami masalah, mempertimbangkan strategi dalam menyelesaikan masalah, serta melakukan refleksi pada proses dan solusi yang dilakukan. Melalui pendekatan Metacognitive Guidance, siswa dapat menangkap informasi esensial dalam permasalahan matematika sehingga mampu menyelesaikannya dengan mudah.

Kegiatan diskusi antar kelompok yang kemudian dilanjutkan dengan diskusi kelas, memungkinkan siswa percaya diri untuk melakukan penemuan sendiri dalam pemecahan permasalahan kontekstual yang diberikan dalam pembelajaran. Selain itu, dengan adanya kegiatan diskusi pada pembelajaran, memungkinkan siswa untuk saling berinteraksi antar teman satu kelompok maupun dengan kelompok lain untuk menyampaikan pendapat, bertanya, menanggapi pendapat orang lain, menjelaskan pemikirannya sendiri dalam memecahkan permasalahan. Selain itu, program GeoGebra juga cenderung lebih efektif dan efisien dalam merekonstruksi bangun-bangun geometri, khususnya pada materi lingkaran, sehingga memudahkan siswa untuk mengeksplorasi lebih akurat mengenai konsep-konsep lingkaran.

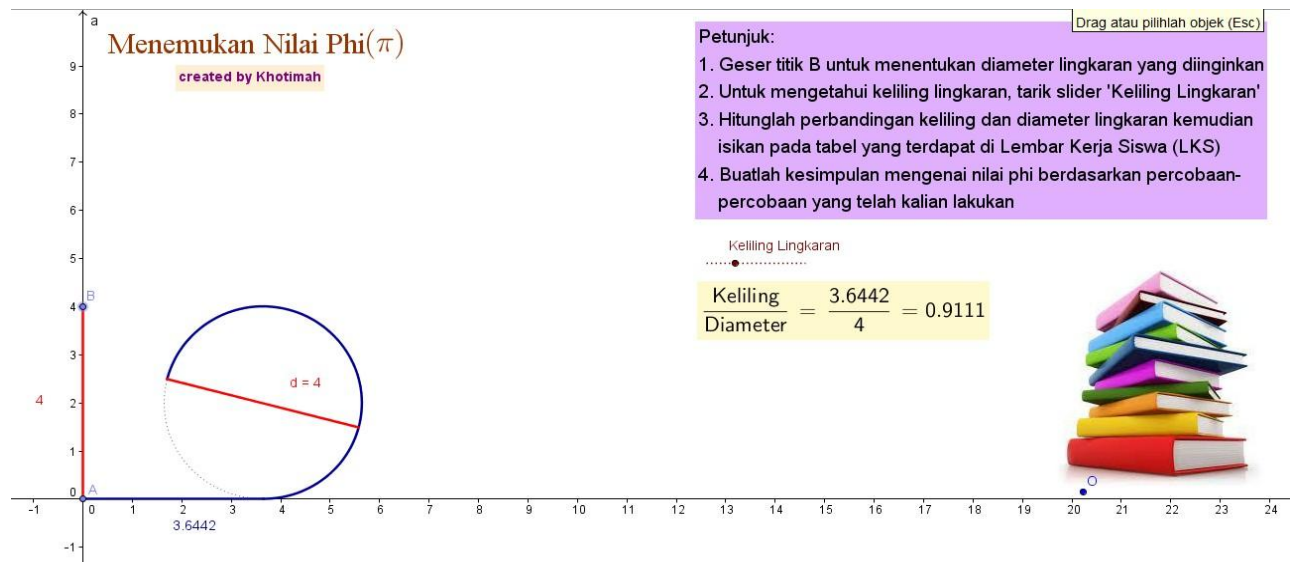

Gambar 1. Contoh Applet GeoGebra untuk Menemukan Nilai Phi $(\pi)$

\section{SIMPULAN DAN SARAN}

Berdasarkan rumusan masalah, hasil analisis data dan pembahasan hasil penelitian sebagaimana yang telah diuraikan di atas, kesimpulan yang diperoleh dari penelitian ini adalah sebagai berikut: 1.a) ditinjau secara keseluruhan, peningkatan kemampuan literasi matematis siswa yang mendapatkan pembelajaran $\mathrm{MG}+\mathrm{GeoGebra}$ lebih baik daripada siswa yang mendapatkan pembelajaran $\mathrm{PB}$; 1.b) peningkatan kemampuan literasi matematis siswa kategori PAM tinggi dan sedang pada kelompok eksperimen lebih baik dibandingkan dengan siswa kategori PAM tinggi dan sedang pada kelompok kontrol; 2) tidak 
terdapat interaksi antara faktor pembelajaran yang diberikan dan kategori PAM (tinggi, sedang, dan rendah) terhadap kemampuan literasi matematis.

Dari hasil penelitian, pembahasan dan kesimpulan, dikemukakan beberapa saran berikut: ditinjau secara keseluruhan pembelajaran dengan pendekatan metacognitive guidance berbantuan GeoGebra ini dapat meningkatkan kemampuan literasi matematis dan self-efficacy siswa. Oleh sebab itu, sebaiknya pendekatan ini diterapkan dalam pembelajaran dalam rangka meningkatkan kemampuan literasi matematis.

Selain itu, bagi peneliti yang ingin menerapkan pendekatan metacognitive guidance berbantuan GeoGebra dalam pembelajaran disarankan untuk menyiapkan applet-applet GeoGebra dan meng-copy-kan semua bahan ajar serta LKS yang memuat aktivitas-aktivitas GeoGebra sebelum penelitian dilakukan agar dapat dipelajari dan dieksplorasi oleh siswa di rumah. Dengan demikian, kelemahan pembelajaran berbantuan GeoGebra yang memakan waktu yang lebih lama dari pembelajaran biasa dapat diatasi dan pembelajaran menjadi lebih efektif. Selain itu, hal ini juga dapat membangkitkan ketertarikan siswa untuk mengeksplorasi sendiri pokok bahasan yang akan dipelajari di sekolah

\section{DAFTAR RUJUKAN}

Bandura, A. (1993). Perceived self-efficacy in cognitive development and functioning. Educational Psychologist Journal, 28(2), hlm. 117-148.

BSNP. (2006). Model KTSP dan model silabus mata pelajaran. Jakarta: BP.Cipta Jaya.

Flavell, J.H. (1979). Metacognition and cognitive monitoring: A new area of cognitive-developmental inquiry. American Psychologist Journal, 34(10), hlm. 906-911.

Mahmudi, A. (2011). Pemanfaatan GeoGebra dalam Pembelajaran Matematika, (Online),

(http://staff.uny.ac.id/sites/default/files/Makalah\%2017\%20Semnas\%20LPM \%20UNY\%202011\%20_Pemanfaatan\%20GeoGebra\%20dalam\%20Pembelaj aran\%20Matematika_.pdf, diakses tanggal 26 November 2014).

OECD. (2013). PISA 2012 assessment and analytical framework: Mathematics, reading, science, problem solving and financial literacy. Paris: OECD Publishing.

Oktaviyanthi, R. dan Supriani, Y. (2015). Utilizing Microsoft Mathematics in Teaching and Learning Calculus. Journal on Mathematics Education, (6) 1, (Online) (http://jims-b.org/wp-content/uploads/2015/03/7-Full-IndoMSJME-61-Rina-Oktaviyanthi.pdf, diakses 01 Agustus 2016).

Oktaviyanthi, R., Agus, R. N. dan Supriani, Y. (2015). Pisa Mathematics Framework dalam Penelusuran Mathematical Literacy Skills Mahasiswa. Jurnal Ilmu Pendidikan STKIP Kusuma Negara, (7) 1, hlm. 77-85, (Online), (https://osf.io/preprints/inarxiv/z2qsf/, diakses 01 Agustus 2016). 
Oktaviyanthi, R. dan Herman, T. (2016, Oktober). A Delivery Mode Study: The Effect of Self-Paced Video Learning on First-Year College Students' Achievement in Calculus. Artikel dipresentasikan pada The $4^{\text {th }}$ International Conference on Quantitative Sciences and Its Applications, Universiti Utara Malaysia, Putrajaya, Malaysia. (Online), (http://aip.scitation.org/doi/abs/10.1063/1.4966102, diakses 01 Januari 2016).

Oktaviyanthi, R., Safaah, E., dan Agus, R. N. (2017). Pemberdayaan Keterampilan Guru Matematika dalam Menyusun Bahan Ajar Berbantuan Mathematics Education Software. Jurnal Pengabdian Masyarakat Wirakrama Parahita, (1) 1, 19-24. (Online), (http://ejurnal.lppmunsera.org/index.php/parahita/article/view/270/523, diakses 10 Januari 2018).

Osborne, J. \& Monk, M. (2000). Good practice in science teaching. London: McGraw-Hill International.

Pratiwi, D. dan Syah, A. A. (2011). Pendekatan metakognitif dalam pembelajaran matematika. Dalam: Ahmad, S, dkk. (Penyunting). Prosiding Seminar Nasional Pendidikan Universitas PGRI Palembang (hlm. 342-348). Palembang.

Sarwiko, D. (2010). Pengembangan media pembelajaran berbasis multimedia interaktif menggunakan Macromedia Director MX (Studi Kasus Mata Kuliah Pengolahan Citra pada jurusan S1 Sistem Informasi). Skripsi tidak diterbitkan. Jakarta: Universitas Gunadarma.

Steen, L. A. (1997). The new literacy: Why numbers count, quantitative literacy for tomorrow's america. The College Entrance Examination Board. New York: The College Board.

Stacey, K. (2012). Mathematical and scientific literacy around the world. Journal of Science and Mathematics Education in Southeast Asia, 33(1), 1-16.

Supriani, Y. dan Oktaviyanthi, R. (2014). The Influence of Compact Disk Interactive Learning Model and Student's Creativity Toward the Understanding of Mathematics Concepts. International Journal of Education and Research, 2 (7), 535-540. (Online), (https://pdfs.semanticscholar.org/cee1/6135957251054ceb0e686eb0bf5d31fc c0fa.pdf, diakses 10 Agustus 2016).

Sutama. (2008). Pengembangan model pembelajaran matematika dengan pendekatan aptitude treatment interaction berbasis fortopolio di SMP kota Surakarta. Skripsi tidak diterbitkan. Universitas Muhammadiyah Surakarta, Surakarta.

Maryanti, E. (2012). Peningkatan literasi matematis siswa melalui pendekatan metacognitive guidance. Tesis tidak diterbitkan. Sekolah Pascasarjana, Universitas Pendidikan Indonesia, Bandung.

McGuinness, C. (1999). From Thinking Skills to thinking classrooms: a review and evaluation of approaches for developing pupils' thinking. London: DfEE, (Research Report RR115), (Online), (http://www.dfes.gov.uk/research/data/uploadfiles/RB115.doc, diakses 26 November 2014). 